\title{
Puasa Selama Kebuntingan terhadap Jumlah Sel Neuron Cereberum dan Cerebellum Rattus norvegicus Baru Lahir
}

\author{
Ucik Nurul Hidayati ${ }^{1 *}$, Hermanto Tri Joewono ${ }^{2}$, Muhammad Miftahussurur ${ }^{3}$ \\ Agus Sulistyono ${ }^{4}$, Martono Tri Utomo ${ }^{5}$, Sulistiawati ${ }^{6}$ \\ Program Studi Magister Ilmu Kesehatan Reproduksi, Universitas Airlangga ${ }^{1}$ \\ Departemen Obstetri dan Ginekologi Rumah Sakit dr. Soetomo Surabaya ${ }^{2}$ \\ Departemen Ilmu Penyakti Dalam Sub Gastro Rumah Sakit dr. Soetomo Surabaya ${ }^{3}$ \\ Departemen Obstetri dan Ginekologi Rumah Sakit dr. Soetomo Surabaya ${ }^{4}$ \\ Departemen Ilmu Kesehatan Anak Rumah Sakit dr. Soetomo Surabaya ${ }^{5}$ \\ Departemen IImu Kesehatan Masyarakat-KP Fakultas Kedokteran Universitas \\ Airlangga ${ }^{6}$ \\ *e-mail: Ucik.nh90@gmail.com
}

\begin{abstract}
Abstrak
Puasa yang dilakukan oleh ibu hamil menyebabkan neuron di otak meningkat. Jumlah sel neuron yang semakin banyak akan mempercepat pemrosesan informasi, sehingga diharapkan akan memingkatkan kecerdasan. Tujuan penelitian ini adalah untuk menganalisa pengaruh puasa selama kebuntingan terhadap jumlah sel neuron cerebrum dan cerebellum Rattus norvegicus baru lahir. Pengambilan sampel pemeriksaan adalah dengan mengambil sampel dari 4 kelompok. Langkah selanjutnya pemeriksaan Hematoksilin-Eosin untuk menghitung jumlah sel neuron pada cerebrum dan cerebellum. Kemudian analisa jumlah sel neuron otak menggunakan uji Desain penelitian yaitu true experimental laboratory post test only with control group design. Sampel penelitian Rattus norvegicus bunting yang terdiri dari 3 kelompok dan 1 kelompok kontrol dengan total sampel sebanyak 32 dibagi 4: kelompok Xo kontrol tanpa perlakuan puasa, kelompok X1 puasa pada trimester 1 ( 2 hari), kelompok X2 puasa pada trimester 2 (2hari), kelompok X3 puasa pada TM 3 (2 hari). Analisis data menggunakan uji normalitas Shapiro-wilk, dilanjutkan dengan uji ANOVA dan tidak terdapat perbedaan bermakna jumlah sel neuron cerebrum pada keempat kelompok $P=0,210 \quad(p>0,05)$ dan terdapat perbedaan bermakna jumlah sel neuron cerebrum pada keempat kelompok $P=0,032$ $(p<0,05)$. Tidak ada perbedaan jumlah sel neuron cerebrum dan cerebellum rattus norvegicus baru lahir pada induk puasa dan tidak berpuasa.
\end{abstract}

Kata Kunci: Puasa, Kebuntingan, Sel Neuron

\section{Fasting During Pregnancy on the Number of Neurons in Cereberum and Cerebellum Rattus norvegicus Newborn}

\begin{abstract}
Fasting by pregnant women causes increasing neurons in the brain. An increasing number of neuron cells will speed up information processing, so it is expected to increasing intelligence. The purpose of this study was to analyze the effect of fasting during pregnancy on the number of new cells of the cerebrum neuron and the newly born Rattus norvegicus cerebellum. The research design was true experimental laboratory posttest only with control group design.
\end{abstract}


Puasa Selama Kebuntingan terhadap Jumlah Sel Neuron Cereberum dan Cerebellum Rattus...

Ucik Nurul Hidayati, Hermanto Tri Joewono, Muhammad Miftahussurur, Agus Sulistyono, Martono Tri Utomo, Sulistiawati

Pregnant Rattus norvegicus samples consisted of 3 groups and 1 control group with a total sample of 32 divided by 4; Xo control group without fast treatment, fasting X1 group in $1^{\text {st }}$ trimester ( 2 days), fasting X2 group in $2^{\text {nd }}$ trimester ( 2 days), fasting group X3 at TM 3 (2 days). Data analysis using Shapiro - Wilk normality test, followed by ANOVA test and using SPSS for Windows 23 software. The results of statistical analysis showed no significant difference in the number of cerebrum neuron cells in the four groups $P=0.210(p>0.05)$ and there were significant differences in the number of cerebrum neuron cells in the four groups $P=0.032$ ( $p$ $<0.05)$. The conclusion of this study is there was no difference in the number of neuron cells in cerebrum and cerebellum of Rattus norvegicus newborn in the fasting mother 2 days during trimester I, II dan III of pregnancy. There was a difference in the number of neuron cells in the new cerebellum of Rattus norvegicus fasting for 2 days during trimester III of pregnancy, and there were differences the effect of the number of neuron cell in cerebellum of Rattus norvegicus in all groups.

Keywords: Fasting, Pregnancy, Neuron Cells

\section{PENDAHULUAN}

Puasa adalah tindakan sukarela
dengan berpantang dari makanan,
minuman, atau keduanya, perbuatan buruk
dan dari segala hal yang membatalkan
puasa untuk periode waktu tertentu. Puasa
dapat menghalangi aktivitas seksual dan
lainnya serta makanan dan sering
dilakukan dalam rangka menunaikan
ibadah, juga dilakukan di luar kewajiban
ibadah untuk meningkatkan kualitas hidup
spiritual seseorang yang melakukannya
(Firmansyah, 2015) Paradigma dalam
masyarakat bahwa puasa yang dilakukan
oleh ibu hamil akan berdampak buruk pada
kehamilan diantaranya pertumbuhan janin
terganggu, kekurangan nutrisi,
meningkatkan hyperemesis gravidarum,
anemia, kenaikan berat badan yang buruk,
kelahiran prematur, berat badan lahir
rendah (BBLR), plasenta lebih kecil
(Mohany et al, 2018). Penelitian yang

dilakukan Abdolhosein menunjukkan bahwa puasa pada ibu hamil memiliki dampak positif terhadap otak, ginjal maupun jantung pada bayi yang akan dilahirkannya dimana puasa akan mempengaruhi sinaptik, neurogenesis dan fungsional pekembangan otak sejak usia kehamilan 3 minggu, selain itu kadar serotonin, Brain derived neurotrophic factor (BDNF), dan nerve growth factor (NGF) plasma meningkat secara signifikan pada ibu hamil yang berpuasa yang merupakan faktor pertumbuhan sel saraf pada otak (Bastani et al, 2017).

Mayoritas besar 70-90\% wanita Muslim hamil melakukan puasa, sebagaimana dibuktikan oleh penelitian dari seluruh dunia, dari Iran, ke Singapura, pedesaan Afrika Barat dan Inggris (Malhotra et al., 2014). Survey di singapura menunjukkan dari 182 ibu hamil muslim, $33 \%$ berpuasa penuh, $54 \%$ berpuasa tidak 
penuh dan sekitar 13\% tidak berpuasa (Joosoph, 2004)

Sedikit sekali penelitian tentang pengaruh ibu berpuasa saat hamil terhadap kondisi bayi yang dilahirkan sehingga menyebabkan kekhawatiran ibu hamil yang ingin melakukan puasa karena anggapan dampak yang buruk untuk kesehatan bayi maupun ibunya. Sebuah penelitian yang telah dilakukan di Guyana membandingkan ibu hamil muslim yang berpuasa di asia dan ibu hamil yang tidak berpuasa, penilaian terhadap berat lahir dilakukan pada ibu yang telah melahirkan. Hasilnya menunjukkan bahwa puasa tidak mempengaruhi berat badan lahir kapan saja puasa dikerjakan (Keith, 2013). Puasa pada ibu hamil dapat meningkatkan fungsi kognitif pada otak dimana pada saat berpuasa jumlah mitokondia pada sel Sel Neuron di otak akan meningkat. Mitokondria membuat potensi sel otak meningkat dan membuat otak lebih banyak menyerap informasi (Achdiyat, 2016). sehingga diharapkan tidak ada kekhawatiran ibu hamil yang ingin melakukan puasa.

Tujuan penelitian ini adalah untuk menganalisa pengaruh puasa selama kebuntingan terhadap jumlah sel neuron cerebrum dan cerebellum Rattus norvegicus baru lahir.

\section{BAHAN DAN METODE}

\section{Desain Penelitian}

Desain penelitian ini yaitu true experimental laboratory post test only with control group design.-Subyek dalam penelitian ini berjumlah 32 , yang terbagi menjadi 4 kelompok, masing-masing kelompok berjumlah 8 ekor yaitu: Kelompok kontrol XO diberikan pakan standart dan air minum, Kelompok X1 diberikan puasa pada trimester I dipuasakan 2 hari (Hari ke 5 dan 6, minggu ke 1 kebuntingan). Kelompok X2 diberikan puasa pada trimester II dipuasakan 2 hari (Hari ke 11 dan 12, minggu ke 2 kebuntingan). Kelompok X3 diberikan puasa pada trimester III dipuasakan 2 hari (Hari ke 17 dan 18, minggu ke 3 kebuntingan).

$$
\text { Puasa selama kebuntingan }
$$
merupakan suatu aktifitas dimana tidak mengkonsumsi sejumlah makanan dan minuman yang berkalori selama 14 jam (jam 17.00-07.00 WIB) dengan komposisi makanan normal 70-100/kgBB/ekor/hari. Pengambilan sampel jaringan otak dilakukan pada kebuntingan hari ke 19 dan segera setelah fetus Rattus norvegicus lahir. Jaringan otak anak Rattus norvegicus diambil untuk dilakukan pemeriksaan HE atau hematoxilyn eosin untuk menghitung jumlah sel neuron. 
Puasa Selama Kebuntingan terhadap Jumlah Sel Neuron Cereberum dan Cerebellum Rattus... Ucik Nurul Hidayati, Hermanto Tri Joewono, Muhammad Miftahussurur, Agus Sulistyono, Martono Tri Utomo, Sulistiawati

\section{Analisa Data}

Analisis data dengan menggunakan uji normalitas Shapiro-wilk dilanjutkan menggunakan Uji ANOVA. Semua perhitungan analisis data tersebut menggunakan software SPSS for Windows 23.
HASIL

Penilaian Jumlah sel neuron dilakukan dengan pewarnaan hemotoksilineosin otak anak Rattus norvegicus. Analisis data mengenai jumlah sel neuron cerebrum dan cerebellum otak Rattus norvegicus dihitung menggunakan statistik deskriptif untuk menunjukkan rata-rata, kemudian dilakukan uji normalitas menggunakan uji Shapiro-Wilk.

Tabel 1. Hasil Uji Normalitas Data Menggunakan Shapiro Wilk

\begin{tabular}{ccc}
\hline Kelompok & N & Nilai p \\
\cline { 2 - 3 } & & Cerebrum \\
\hline X0 & 6 & 0,354 \\
X2 & 6 & 0,922 \\
X3 & 6 & 0,237 \\
\hline
\end{tabular}

Keterangan: X0: Kontrol/ tidak puasa; X1: Puasa Trimester 1; X2: Puasa Trimester 2; X3: Puasa Trimester 3.

Hasil uji normalitas data jumlah sel neuron Cerebrum berdistribusi normal $(p>$ $0,05)$. Setelah dilakukan uji normalitas data maka didapatkan bahwa jumlah sel neuron pada cerebrum berdistribusi normal semua antara kelompok control dan kelompok perlakuan kemudian dilanjutkan dengan uji homogenitas didapatkan hasil data homogen $p=0,806 \quad(p>0,05)$, kemudian dilakukan uji ANOVA

Tabel 2. Perbedaan Jumlah sel neuron Cerebrum antara kelompok Kontrol, Puasa Trimester 1, 2 dan 3

\begin{tabular}{cccc}
\hline Kelompok & N & Median (min - maks) & Nilai $p$ \\
\hline X0 & 6 & $16,80 \pm 3,76$ & \\
X1 & 6 & $14,07 \pm 4,22$ & 0,210 \\
X2 & 6 & $17,73 \pm 4,49$ & \\
X3 & 6 & $13,47 \pm 3,21$ & \\
\hline Keterangan: X0: Kontrol/tidak puasa: X1: Puasa Trimester $1 \cdot$ X2: Puasa Trimester 2: X3: Puasa Trimester
\end{tabular}

Keterangan: X0: Kontrol/ tidak puasa; X1: Puasa Trimester 1; X2: Puasa Trimester 2; X3: Puasa Trimester 3.

Tabel diatas menunjukkan tidak terdapat perbedaan bermakna jumlah sel neuron Cerebrum pada keempat kelompok $P=0,210(p>0,05)$

Hasil uji normalitas data jumlah sel neuron Cerebrum pada keempat kelompok berdistribusi normal $(p>0,05)$. Setelah dilakukan uji normalitas data maka didapatkan bahwa jumlah sel neuron pada cerebellum berdistribusi normal semua kemudian dilanjutkan dengan uji homogenitas didapatkan hasil data homogen $p=0,251 \quad(p>0,05)$, kemudian dilakukan uji ANOVA 
Tabel 3. Perbedaan Jumlah sel neuron Cerebellum antara kelompok Kontrol, Puasa Trimester 1, 2 dan 3

\begin{tabular}{cccc}
\hline Kelompok & $N$ & Rerata \pm Simpangan Baku & Nilai $p$ \\
\hline X0 & 6 & $17,17 \pm 2,687^{\mathrm{a}}$ & \\
X1 & 6 & $13,17 \pm 2,832^{\mathrm{ab}}$ & 0,032 \\
X2 & 6 & $16,03 \pm 4,561^{\mathrm{a}}$ & \\
X3 & 6 & $11,57 \pm 2,902^{\mathrm{b}}$ & \\
\hline
\end{tabular}

Keterangan: X0: Kontrol/ tidak puasa; X1: Puasa Trimester 1; X2: Puasa Trimester 2; X3: Puasa Trimester

3.

Hasil analisis varian menunjukkan terdapat

kehamilan dan stress oksidatif dalam tubuh perbedaan bermakna jumlah sel neuron akan semakin sedikit sehingga penggunaan Cerebellum pada ke-empat kelompok ( $p>$ badan keton akan semakin sedikit sehingga 0,05). Hasil uji lanjut ANOVA menggunakan LSD menunjukkan kelompok X3 berbeda dengan $\mathrm{X} 0$ dan $\mathrm{X} 2$ tetapi tidak berbeda dengan X1.

\section{PEMBAHASAN}

Hasil penelitian menunjukkan bahwa tidak terdapat perbedaan bermakna jumlah sel neuron Cerebrum dan Cerebellum antara kelompok kontrol dan puasa trimester 1 ( $p>0,05)$. Trimester 1 merupakan periode embrionik dimana yaitu terjadinya proses organogenesis, termasuk perkembangan otak dimana otak sedang dalam pertumbuhan yaitu proses pembentukan neuron, gliogenesis, migrasi sel, dan diferensiasi awal termasuk didalamnya pembentukan sinaps dan mielinisasi (Morgane et al, 1993). Mekanisme yang mendasari yaitu yang mempengaruhi sel neuron berhubungan dengan nutrisi dan tersediannya faktor neurotropik (Sani dan Beni, 2007).

Pada kehamilan trimester 1 tubuh masih beradaptasi dengan hormon jumlah sel neuron tidak terjadi perbedaan yang bermakna anatara ibu hamil yang berpuasa di trimester 1 dengan ibu hamil yang tidak berpuasa.

Hasil penelitian menunjukkan bahwa tidak terdapat perbedaan bermakna jumlah sel neuron Cerebrum dan Cerebellum antara kelompok kontrol (X0) dan puasa trimester $2(X 2)(p>0,05)$. Pada kehamilan trimester 2 , tubuh sudah mulai beradaptasi dengan hormon kehamilan dan nutrisi yang masuk ke tubuh sudah mulai meningkat.

Saat melakukan puasa maka tubuh akan kehilangan cadangan makanan sehingga memaksa lemak yang ada dijaringan adipose untuk memecah menjadi asetil KoA, selanjutnya asetil KoA akan diubah menjadi badan keton, badan keton akan mempengaruhi stress oksidatif untuk menurunkan ROS yang akan mempengaruhi neurotransmitter yang ada di sel neuron yang memiliki ion ion antara lain glutamate dan $\mathrm{Ca} 2+$ influx yang akan berikatan dengan CAMK kemudian 
Puasa Selama Kebuntingan terhadap Jumlah Sel Neuron Cereberum dan Cerebellum Rattus... Ucik Nurul Hidayati, Hermanto Tri Joewono, Muhammad Miftahussurur, Agus Sulistyono, Martono Tri Utomo, Sulistiawati

berfosorilasi dengan CREB yang selanjutnya akan merangang mRNA BDNF untuk menjadi BDNF, kemudian BDNF akan berikatan dengan reseptornya yaitu TrKB yang akan mempengaruhi proses proliferasi, diferensiasi, migrasi, synaptogenesis, apoptosis dan mielinisasi yang akan meningkatkan jumlah sel neuron (Georgieff et al, 2018)

Hasil penelitian menunjukkan bahwa terdapat perbedaan bermakna jumlah sel neuron Cerebrum dan Cerebellum antara kelompok kontrol dan puasa trimester $3(p<0,05)$. Pada kehamilan trimester 3 nutrisi yang masuk ke tubuh semakin meningkat, karena pada periode ini tubuh membutuhkan lebih banyak nutrisi untuk pertumbuhan dan perkembangan janin. Nutrisi yang semakin meningkat dan melakukan puasa maka stress oksidatif pada tubuh akan semakin meningkat sehingga tubuh akan menggunakan badan keton (BHB) semakin banyak lagi dan menyebabkan sel neuron semakin meningkat (Georgieff et al, 2018), sehingga terdapat perbedaan bermakna sel neuron cerebellum antara kelompok kontrol dan puasa trimester 3 .

Hasil penelitian menunjukkan bahwa terdapat perbedaan bermakna jumlah sel neuron Cerebellum antara kelompok kontrol dan puasa trimester 3 $(p<0,05)$. Sedangkan pada cerebrum tidak terdapat perbedaan bermakna jumlah sel neuron Cerebellum antara kelompok kontrol dan puasa trimester $3(p<0,05)$. Program kematian sel neuron pada janin di dalam kandungan terdiri dari dua proses yaitu proses nekrosis yang bersifat patologis dan proses apoptosis yang bersifat fisiologis. Program tersebut dipengaruhi oleh ekspresi beberapa gen dan dapat dicegah dengan penyerapan beberapa Neurothropic factor (Stiles and Jernigan, 2010). Sel neuron akan berhenti menjalani multiplikasi pada waktu lahir. Dengan demikian, maka sel neuron akan berhenti bertambah banyak sebelum kita lahir (Rodeck and Whittle, 1999). Neuron diproduksi dalam jumlah yang sangat banyak dan jumlah sel ini akan diregulasi oleh kematian sel yang terjadi saat periode konektivitas ke jaringan target. Secara alami apoptosis neuron berguna agar neuron membentuk koneksi yang tepat dengan targetnya. Neuron yang sedang tumbuh berkompetisi untuk mendapatkan faktor neurotropik yang terbatas jumlahnya yang diproduksi target jaringan.

Otak yang tumbuh pada trimester 3 mempunyai korteks lebih tebal, inti sel neuron lebih besar dan sel glia lebih banyak. Ditemukan juga sel neuron otak yang tumbuh dengan lingkungan kaya stimulus mempunyai dendritic site lebih banyak sehingga memungkinkan terbentuk 
sinaps lebih banyak. Rees and Walker (2011) juga menyatakan jumlah sel yang mengalami apoptosis tergantung dari sinaps, makin banyak sinaps makin sedikit apoptosis yang terjadi. Makin kaya sel neuron akan dendritic site makin banyak sinaps yang terbentuk, sehingga jumlah sel yang mengalami apoptosis juga akan berkurang. Otak yang tumbuh akan mengalami apoptosis lebih sedikit dan mengakibatkan peningkatan jumlah sel neuron (Rees and Walker, 2011). Pada cerebellum tidak terdapat perbedaan yang bermakna antara kelompok kontrol dan puasa trimester 2, hal ini diduga disebabkan karena fungsi dari cerebellum adalah keseimbangan dan koordinasi otot, sedangkan cerebrum berfungsi sebagai kognitif, berfikir dan ingatan.

\section{KESIMPULAN}

Kesimpulan hasil penelitian ini adalah Tidak ada perbedaan jumlah sel neuron cerebrum dan cerebellum Rattus norvegicus baru lahir pada induk puasa maupun yang tidak berpuasa.

\section{DAFTAR PUSTAKA}

Bastani A, Rajabi S, Kiamimarkani F, 2017. The effect of fasting during ramadhan on the contraception of serotonin, dopamine, Brain derived neurotropic factor and nerve growth factor. Neurol Int. 9(2):

Georgieff MK, Ramel SE, Cusick SE, 2018. Nutritional Influences on Brain Development. Acta Paediatr. 107(8): 1310-1321.

Joosoph J. Abu, J. 2014. A survey of fasting during pregnancy. Singapore; Departemnt of obstetric and gynecologyWomen's and children

Mohany $\mathrm{M}$, Ashton $\mathrm{N}$, Harrath $\mathrm{AH}$, Nyengaard JR, Alomar SY, Alwasel S, 2018. A New Model for Fetal Programming: Maternal Ramadhan Type Fasting Program Nephrogenesis. Journal of Development Origins of Health and Disease. 9(3): 287-298.

Morgane PJ, Austin-LaFrance R, Bronzino J, Tonkiss J, Diaz-Cintra L et al, 1993. Prenatal Malnutrition and Development of the Brain. Neurosci Biobehav Rev. 17(1): 91128.

Rees S and Walker D, 2011. Fetal growth and Development in R. Harding and A. Bocking, eds. Nervous and Neuromuscular Systems. Cambridge: Cambridge University Press. pp.154-85. 
Puasa Selama Kebuntingan terhadap Jumlah Sel Neuron Cereberum dan Cerebellum Rattus... Ucik Nurul Hidayati, Hermanto Tri Joewono, Muhammad Miftahussurur, Agus Sulistyono, Martono Tri Utomo, Sulistiawati

Rodeck $\mathrm{CH}$ and Whittlle MJ, 1999. Fetal

Medicine: Basic Science and

Clinical Practice. Churchill

Livingstone.
Stiles J and Jernigan TL, 2010. The Basics of Brain Development. Neuropsychol Rev. 20(4): 327-348. 